\title{
ANCIENT GREEK MILITARY THEORY AND PRACTICE. AENEAS TACTICUS (I)
}

\author{
Dana DINU \\ University of Craiova, Romania \\ dinudana9@yahoo.com
}

\begin{abstract}
The intention of this article is to present the oldest surviving work of military art of the Greek antiquity written in the mid-fourth century B.C. by of the author known today as Aeneas Tacticus. In 1609 Isaac Casaubon, its first editor, gave it the Latin title Commentarius de toleranda obsidione, How to Survive under Siege. Aeneas Tacticus was an experienced general on the battlefield, and had an equally solid theoretical training based on treatises of warfare which undoubtedly existed before his own, but were less fortunate and have not reached us. The study of this manual reveals that Aeneas Tacticus wrote or designed to write at least five books on military themes and information exists from other sources that he might have written three more books on the subject. Thus, all these works could have formed a Corpus Aeneanum, comparable in value to Clausewitz's famous work On War. Aeneas's work was highly appreciated and extremely useful for commanders and strategists of the Antiquity and the Middle Ages and was used and cited by all the authors of treatises on siege until the era of pre-modern warfare.
\end{abstract}

\section{Keywords: Aeneas Tacticus, treatise, pre-modern warfare, siege}

\section{Introduction}

We owe the discovery and the spreading of this treatise by Aeneas Tacticus to Isaac Casaubon, who published it as a supplementum to his 1609 edition of Polybius, Orelli tells us. And it was Orelli himself, Aeneas' modern publisher [1], who noted that, for more than two centuries after the editio princeps of this work, the text remained largely ignored by publishers and critics, notwithstanding Casaubon's very scholarly commentary. One of the reasons for this lack of interest in the lapse of time between the two editions might be that, at the moment of the first printed edition, the military theory, practice and logistics had largely evolved, making the Renaissance and post-Renaissance military specialists to discard it as obsolete. Since Orelli's publication in the nineteenth century the number of new editions, comments and studies dedicated to this treatise increased, all manuscripts [2] of the original Greek text were subjected to thorough examination and were translated in some of major modern languages.

Its value is praised by $H$. Delbrück, a historian of warfare art, from different perspectives: "The first comprehensive work on military theory, free of any poetic trapping and oriented directly toward practical applications, came from the pen of an Arcadian, the Stymphalian Aeneas, who, using Xenophon as a source, wrote around the year 357 B.C. Only one of the various books of this work, that dealing with the defence of a city, has come down to us, and even it does not give us very much information. Most of the book is taken up with precautionary measures against treason, stratagems of war, secret writing, telegraphy and general observations. Nevertheless, the book contains but little concerning siege machines and countermeasures for the defence, and even this little is possible a later interpolation." [3]. In addition to its 
documentary value for the military historiography and for the historic field in general, this manual is a solid complimentary source for studies concerning the Ancient Greek mercenary [4] or the role played by the hoplite troupes in the defence of the city [5], the social relations within the city, the social conflicts, the relations between citizens and outsiders. At the same time it constitutes a valuable source for specific military terms related to the siege and for the technical vocabulary concerning tools of the city defence apparatus.

\section{Warfare evolution in the Greek world}

Information about the very early Greek antiquity, approximately twelfth century B.C., comes down to us from a few iconographic materials found in Crete, including information in the linear B (the oldest attested script form of Greek) about the chariot fights. This was the quite advanced warfare technology of the Hittites, which later on spread in the whole of the Middle East and Egypt and was adopted by the Greeks. Of the Bronze Age, the siege of the city of Troy is the best known and the best documented war. Homer is in this, as in so many other aspects concerning the antiquity, the first important reference for the Greek warfare art and in particular, for siege warfare. It is from Homer's epic poem that we know that in Troy the warring Greek elite made use of battle chariots. But this type of battle, specific for the Bronze Age and for a specific social and political system of organization, did not last long with the Greeks. The mainland and the Peloponnese did not have the necessary space for a type of conflict mainly suited for the plains, whereas the largely mountainous Greek landscape did not favour it. In time, the iron smelting technique enabled the Greeks to manufacture more efficient arms, thus leading to more advances in their warfare approach, at a time when radical social, political and not in the least economic changes took place, marking the end of the Bronze Age. After the eighth century B.C. this led to the birth of independent citystates and, more often than not, to the inevitable rivalries between them. Later on, the hoplite revolution broke out in cities with a democratic constitution, such as Athens, and brought about an increased role of the common citizens in the city wars. This will produce a crucial consequence on the political playground, as Aristotle demonstrated, namely a greater participation of the demos in the city governance, hence to democracy. It was patriotic pride, as well as duty, which made the Greeks into citizens and soldiers. But never simultaneously, since the citizens were intrinsically landowners and could only serve as active soldiers outside the agricultural season. Consequently the wars they fought were season-bound. Citizens' solidarity was forged on the battlefield and this is nowhere more evident than in the way the so-called Greek phalanx - the formidable battle formation - was born, with comradeship as an important lubricant and factor of success. Compared to the wars in the archaic period, those which follow are re-dimensioned, as the length and the stakes of the confrontations change, with different social groups involved and with other interests than in past conflicts. In the Trojan War for instance, which went on for ten years, several Greek cities formed an alliance and its outcome was decided by some ambitious warring aristocrats in search of the glory brought by individual acts of bravery. In about eight hundred years between the Trojan War and the middle of the fourth century, the approximated moment of the completion of Aeneas Tacticus' treatise, the Greeks amassed a great deal of experience on the battle field. Some of their strategists and specialists in the art of warfare put this experience to use in theoretical materials, which led to several practical guides for 
military confrontations, and more specifically, for defence in siege situations. But, except for Xenophon's writings on the cavalry commander and the art of equitation - though not proper warfare treatises - only one treatise reached us, that of Aeneas, or Aeneas Tacticus, as his first editor called him.

\subsection{Identity of the author of this treatise}

The question of determining the identity of author of this treatise is crucial, because establishing its authorship with a reasonable degree of certitude also implies a greater degree of certitude concerning the period of its conception. One thing is beyond doubt, the fact that the author's name is Aeneas and that it refers to a real person. This identification is mainly owed to Polybius, also of Arcadian origin, one of the earliest sources on Aeneas and separated from him by approximately two centuries.

Another argument pleading for Aeneas seems to be present in the actual text, as if the author introduced his cryptic signature, precisely in chapter $31.18-19$ where he speaks about cryptography, even if this fragment shows gaps and is very difficult to interpret. The name of Aeneas is not found in the existing manuscripts, but the text critics managed to identify the sequence aine- in the altered fragment, thus finding a solid argument to support the assumption that the name of the author is Aeneas. [6]. As for the cognomen Stymphalius, the earliest source naming Aeneas Stymphalius as its author is Cineas from Thessaly, a friend and adviser to King Pyrrhus of Epirus. Cineas put together a compilation of the treatise, which enjoyed a large circulation in the Greek and Roman world and is considered by some philologists as the actual treatise known to us today.

Concluding, one can affirm with a certain degree of probability that the author of the treatise is Aeneas Stymphalius, of Arcadian origin, the same successful and vastly experienced general Xenophon mentioned in Hell., VII, 3,1.

\subsection{Nature of the guidebook}

There are many debates regarding the relation between the titles given by some editors and the content of the guidebook, in other words, to establish which one, between the part concerning the tactics and that of preparing the city for a siege situation, is defining for the nature of this work. As for Casaubon, he grants the author the epithet of Tacticus, placing him - as Aelianus had before him - [7], among those who wrote treatises on tactics.

On the other hand, some commentators consider that the treatise, or better, its preserved fragment, does not have battle tactics as a main topic, therefore the epithet Tacticus would be unjustified.

However one should notice that, by giving it the Latin title of Commentarius tacticus et obsidionalis, Casaubon underlines both of the aspects present in the manual, the one concerning the siege prevaling. In the first and third chapter, Aeneas writes about the organisation of the besieged troops and the idea of tactics becomes evident here. As for Aelianus, when he defines the term of tactics in chap. 3.4, he cites Aeneas as a trusted source for "the science of military movements", scientia bellicorum motuum. Many centuries later, the editor Arnold Hug, gives it the title Commentarius Poliorceticus, showing the relevance of the content about the modalities of resisting a siege, and he names the author simply as Aeneas, without any other cognomen to underline his military inclination [8].

\subsection{Aeneas Tacticus, scriptor castrensis}

As the author of several military works, Aeneas Tacticus is essentially a scriptor castrensis. According to some commentators, these works might form a Corpus Aeneanum. We are aware about five of these works already published or intended to be written from the very content of the treatise that survived. Unfortunately, the others did not reach us, either because they were lost or because they did not go beyond the project fase. Thus, Aeneas 
mentions the work De rei bellicae apparatibus, On Preparations of War; on three occasions, in 7.4, 8.5 and 40.8; in 14.2, he talks about the book De praesidiis belli comparandis, On funding the war; in chapter 21.2, he reveals his intention to start working on De castrametatione, On the Settlement of the Camp; a fourth work which is mentioned in 11.2 deals with the subject of conspiracies and about the fifth we learn in 38.5, namely Liber auditarum narrationum, a title with no clear indication about the content. In addition, the title Classis Ordinatio, On naval tactics of the last chapter of the treatise On siege, which we discuss în the present article, would actually announce the subject of a future book. But not all commentators agree that this was an autonomous work and would not have belonged to the handbook we are discussing, although the lack of continuity with the rest of the subject seems to be obvious. In addition to the mentioned works, by virtue of the fact that Aeneas Tacticus was regarded as one of the authors who wrote on poliorcetics, it has been speculated that he might have written a separate work on besieging a city, as a necessary counterpart of the manual on defending a city under siege. And this might have been a seventh book.

Also, based on the testimony of Aelianus Tacticus, who quotes Aeneas's definition of the term tactics, the assumption that Aeneas was also the author of work on tactics becomes rather credible. Apparently there was another work about which Polybius informs us in X, 40, in which Aeneas talked about the use of the light signals to remotely transmit encrypted information, the so-called optical telegraphy. Together with the manual on defence in the event of a siege, Aeneas's only preserved but incomplete work, Corpus Aeneanum would have been made up of ten books, covering a very broad military range of themes.

\subsection{Determining the date of the writing of the treatise}

In order to determine the time when this manual was written, intra-textual as well as extra-textual information may be used. Regarding the first category, we can identify in the text of Aeneas a series of significant historical markers. The historical events evoked by Aeneas are numerous, but only twenty of them are accurately datable [9]. They are located in the time span between $700 \mathrm{BC}$ and $360 \mathrm{BC}$, a fairly wide range, in which many events occurred in the military history of the Greek cities. Of this, the author selects those episodes he considers useful for providing examples for the future, he comments on them from the point of view of defensive strategy and makes them available to military art specialists. Historical references are summoned by Aeneas in order to exemplify or illustrate a particular issue he wants to demonstrate. The treatise makes no use of chronological deployment of these evoked historical episodes they are successively mentioned to serve the demonstrative intent. Most episodes are concentrated in the first half of the 4 th century BC, between 397 and 360, of course not by chance, because, apparently, this was the period of time when Aeneas had activated on the battlefield. The last reported event appears in chapter 24 and is located approximately in the centre of the book, in the form that reached us. This chapter deals with passwords, De tesseris, and how to make them difficult for the enemy to crack. To illustrate the crucial importance of the passwords in the defence of the city, Aeneas recounts, among other things, the episode of the conquest of Ilion by Charidemus, which is certainly known to have taken place in 360 BC. Events after this year, although very important to the military history of Greece, as for example the reign of Philip II and Alexander the Great, are not included in this document. All this corroborated information leads to the conclusion that Aeneas did not write the treatise before $360 \mathrm{BC}$, which can be 
considered as terminus ad quem. At the same time, the reference to the custom of the Locri inhabitants to send virgins to Ilion shows that the writing did not occur beyond 346 , the year when this habit was abolished, according to Timaios, [10] and can be considered a terminus a quo. Therefore, it is most likely that the writing interval of the manual can be set between 360-346 B.C. In addition to these chronological references, the work itself contains other dating items. Thus, the German philologist Alfred von Gutschmid observed that, in order to illustrate a type of coded text messages, in chapter 31.31, Aeneas uses an example that refers to events that took place shortly before, since the two names that appear here, Dionysius and Herakleides, were involved in a war at that time. It is known from other sources that in the autumn of 357 BC, Dionysius II of Syracuse was at war with Dion and Herakleides from Peloponnese. Learning that Dionysus is no longer in power, Dion writes to Herakleides to join him. The encoding proposed by Aeneas is the replacement of the vowels with a dot system. It can therefore be inferred that the year $357 \mathrm{BC}$ is another landmark, limiting the drafting date of this treatise and showing that it could have only been written a posteriori. The fact that Aeneas's work circulated in the form of a compendium put together by Cineas, the advisor and friend of King Pyrrhus of Epirus (318-272 BC) is supported by documents. Pyrrhus was one of the greatest generals of the Hellenistic era, and the fact that he asked his counsellor to provide him with an abbreviated version of the book shows that Aeneas was the author of a work considered useful and enjoyed the appreciation of military art practitioners. More than two hundred years later, the compendium of Cineas was still outstanding and was known even in Rome. For example, in a letter addressed to $\mathrm{L}$. Papirius Paetus, Cicero recalls this work and its author: Plane nesciebam te tam peritum esse rei militaris. Pyrrhi te libros et Cineae video lectitasse (I had not the slightest idea that you were such an expert in military matters. You have evidently perused the commentaries of Pyrrhus and Cineas). [11]. We also know from Cicero that Cineas had listened to Epicurus in Athens at the end of the CXVIII Olympics (305 BC) and that he was sent by Pyrrhus to Rome in the second year of the CXXV Olympics (279 BC). This is indirect, but important information for data corroboration and for establishing a time frame in which the Aeneas's treatise was drafted. It also enables us to form an idea of the practice it established and of the reception it enjoyed in its time.

\section{Conclusions}

Aeneas's work belongs to the technicaldidactic literature, the so-called artes. We have no knowledge of any author or manual in the military field before Aeneas. However, we can count Xenophon as the only known precedent with the works I have already mentioned, to which we can add the passages describing various military actions spread in his vast work. But these are not treatises or textbooks of military art, even if they belonged to the culture of the authors of actual artes. It is not by accident that Aelianus Tacticus puts Aeneas Tacticus right after Homer, the author who recounts in a poetic form the most famous successful siege in history. In chronological order, Aeneas is most probably the first Greek author, undoubtedly a military professional, to write military technical literature. Aeneas himself does not mention any predecessor, as Xenophon does, for instance, in his treatise on horsemanship. It is quite possible that there was no precedent in the strict sense of the word treatise or textbook. But most certainly the works of great historians as Herodotus or Thucydides or others, contained descriptions of major battles, sieges, and many stories and anecdotes about commanders and exploits 
that deserved to be recorded. The tradition of wartime narratives also provides a rich anecdotal and military experience. But
Aeneas himself does not explicitly claim any heritage of any prior model or source.

\section{References}

[1] Aeneae Tactici Commentarius de toleranda obsidione, Graece ad codices Mss. Parisienses et Mediceum recensuit, versionem Latinam et commentarium integrum Is. Casauboni, Notas Iac. Gronovii, G. H. Koesii Caspari Orellii aliorumque et suas adiecit Io. Conradus Orellius, Lipsiae, in Libraria Weidmannia, MDCCCXVIII.

[2] Dain, Alphonse, „Les manuscrits d'Énée le tacticien”, Revue des Études Grecques, Tome 48, fascicule 224, pp. 1-32, Janvier-Mars, 1935, doi: 10.3406/reg.1935.4944 $\mathrm{http} / / / \mathrm{www} . p e r s e e . f r / d o c / r e g \_0035-2039 \_1935 \_n u m \_48$ 224_4944

[3] Delbrück, H., Warfare in Antiquity. History of the Art of War, Volume 1, Translated from the German by Walter J. Renfroe, Jr., University of Nebraska Press, Lincoln and London, 1990, p. 163.

[4] Trundle, Matthew, Greek Mercenaries. From the Late Archaic Period to Alexander, Routledge, Taylor \& Francis Group, London and New York, 2004, passim.

[5] Burliga, Bogdan, "The Importance of the Hoplite Army in Aeneas Tacticus' Polis", The Greek World in the 4th and 3rd Centuries BC, Jagiellonian University Press, Kraków, 2012, ELECTRUM * Vol. 19 (2012), pp. 61-81 doi:10.4467/20843909EL.12.003.0744

[6] Williams, Hudson T., "The Authorship of the Greek Military Manual Attributed to 'Aeneas Tacticus'", The American Journal of Philology, Vol. 25, No. 4 (1904), pp. 390405.

[7] Aelianus Tacticus, De instruendis aciebus, Latin Translation by Theodorus Gaza, Joannes Sulpitius Editor, Roma, Eucharius Silber, 1487, pp. 2-3, https://ia902606.us.archive.org/19/items/ita-bnc-in2-00000707-001/ita-bnc-in200000707-001.pdf

[8] Hug, Arnoldi Prolegomena critica ad Aeneae Poliorcetici editionem, Turici, Typis Zürcheri et Furreri, 1874.

[9] Cf. Hug, Arnold, Aeneas von Stymphalos. Ein arkadischer Schriftsteller aus classicher Zeit, pp. 5-8.

[10] Preserved in Lycophron scholia, v. 1144, Scheer editor, Apud Siege Defense by Aeneas Tacticus, Loeb Classical Library edition, 1928, p. 5 and note 6.

[11] Cicero, The Letters to His Friends, With an English translation by W. Glynn Williams, London, William Heinemann Ltd, Cambridge, Massachusetts, Harvard University Press, 1952, IX, 25, pp. 278-279. 